\section{In this issue: \\ Guidelines for ACRL Chapters . ..301}

Continuing Education-VII .....303

News from the Field ..........304

People ..................315

Publications ...............317

Classified Advertising $\ldots \ldots \ldots .320$

\section{COLLEGE \\ \& RESEARCH LIBRARIES MQNIS}

NO. 10 - NOVEMBER 1978

\title{
Guidelines for ACRL Chapters
}

\section{BACKGROUND}

The following statement appeared in the 1956 ACRL Organization Manual:

The ACRL chapter is an important means of connecting a local or regional group of college librarians with the national organization and its headquarters. The chapter charts its own course. The only requirement is that it hold annual or biennial meetings and report annually. Members of chapters are not even required to be members of the national association (officers are expected to be).

Although the Constitution has always made provision for chapters, none was established until a group in the Philadelphia area organized and obtained approval from the Board of Directors late in 1951 .

Chapters have already proved to be far more useful than was originally anticipated. It was expected that some chapters would wither on the vine, but so far all seem to have had healthy growth. They provide a device for all members who so wish to participate in the ACRL program locally if not nationally. The chapter is a handy framework within which librarians can meet for social purposes and consider professional problems of local importance. In some cases, chapters undertake studies or perform cooperative services. The chapters help to draw people into ACRL membership and participation in the national organization.

\section{Organization}

Article VI, Section 4 (c), of the ALA Bylaws states: "A division may affiliate with itself regional, state, or local groups interested in the same field of library service or librarianship. Such groups may admit members who are not members of the division or of the Association."
The ACRL Bylaws provide for chapters as follows:

\section{Article IV. Chapters}

Sec. 1. Establishment. The Board of Directors may establish a chapter of the Association in any state, province, territory, or region on the petition of twenty-five members of the Association residing or employed within the area.

Sec. 2. Bylaws. A chapter may adopt its own bylaws provided there is no conflict between them and the Constitution and Bylaws of the Association.

Sec. 3. Members. A chapter may admit members who are not members of the Association.

Sec. 4. Meetings. Each chapter shall hold at least one meeting a year unless it is affiliated with an organization that normally meets biennially.

Sec. 5. Reporting. Each chapter shall send a report of its meetings to the executive secretary of the Association within one month following the meeting.

Sec. 6. Dissolution. A chapter may be dissolved at its request by the Board of Directors of the Association and shall be so dissolved if it becomes inactive or fails to comply with the provisions of this article.

\section{PETITION}

The petition for chapter status should read as follows: "The following persons hereby petition for chapter status in the Association of College and Research Libraries, under the name [name of proposed chapterl and covering the geographic area [location and/or geographic coverage]. The purpose and objectives of the chapter will be as follows: [state briefly]." List the name, address, and telephone number of the individual acting as chairperson. Include the signatures of at least 
twenty-five ACRL members and a typed alphabetical list, with complete addresses, of those signing the petition.

\section{APPROVAL}

Forward the petition to the Executive Secretary, Association of College and Research Libraries, 50 E. Huron St., Chicago, IL 60611. The petition for chapter status will be considered at the next meeting of the ACRL Board of Directors, if received one month prior to that meeting. Notification of the board's action will be sent to the acting chairperson as soon as possible after the board meeting.

\section{Status and Obligations}

ACRL chapters are completely autonomous except as provided by the ACRL Constitution and Bylaws. They may (1) adopt bylaws governing officers, membership meetings, committees, and other matters; (2) develop and implement their own programs, requesting assistance from the ACRL Executive Secretary; (3) establish criteria for dues and membership; or (4) develop a newsletter or engage in other activity in order to improve communication within the membership.

ACRL chapters must (1) hold at least one meeting a year, unless affiliated with an organization that normally meets biennially; (2) send to the ACRL Executive Secretary, within one month following a meeting of the chapter, a written report including a summary of the meeting and a list of the chapter's officers, with addresses and telephone numbers; and (3) provide funds to support the activities of the chapter

\section{AsSistance}

The ACRL Executive Secretary is available to assist chapters in developing programs and planning activities, as well as to provide other advice as needed.

The ACRL Chapters Committee, constituted from the ACRL membership in active chapters, is responsible for providing assistance in the formation of chapters; improving the relationship between the chapters and ACRL and thus between academic librarians and the national organization; conducting an annual survey of chapters and compiling information for the benefit of all chapters in order to promote the exchange of information; and developing programs for encouraging membership in ACRL.

Existing ACRL Chapters: Southern California, Delaware Valley, Florida, Illinois, Kansas, Maryland, Michigan, Minnesota, Missouri, New England, Eastern New York, Western New York Ontario, North Carolina, Oregon, Tennessee, Texas, Tri-State, Virginia, Wisconsin.

Reprints of these guidelines are available from the ACRL office, $50 \mathrm{E}$. Huron St., Chicago, IL 60611

\section{Data-Banks Symposium}

An International Symposium on Animal Health and Disease Data Banks, sponsored by Animal and Plant Health Inspection Service and Technical Information Systems, Science and Education Administration, U.S. Department of Agriculture, will be held on December 4-6 at the National Agricultural Library, Beltsville, Maryland.

The symposium is designed to promote awareness of and develop ongoing cooperation among established data banks and other information systems. Primary users and other interested persons are also invited to attend. Registration for attendance will be limited to 200 persons. Brief, concise descriptions of data banks will be presented by participating authorities.

Time will be scheduled for informal discussions. The Symposium Proceedings will include papers that could not be presented in person, together with papers presented during the program. Summary papers and stateof-the-art reviews will be included. A directory of specialized animal health and disease data banks will also be published later using information taken from a form questionnaire. The directory will include data banks that could not be represented at the symposium.

Persons interested in participating or who wish a program brochure, contact Dr. Edwin L. Pilchard, Emergency Programs Information Center, U.S. Department of Agriculture, Room 757, Federal Building, Hyattsville, MD 20782, (301) 436-8418.

News items for inclusion in CLRL News should be sent to John V. Crowley, Assistant Director of Litraries, Milne Library. State University College, Onoonta. NY 13820 Oisplay advertis. ing should te sent to Leona Swiech. Advefising Otfis Afret can Litrary Assocution 50 E Huron St Oicago. IL 6061: Send clarsified ads to ACRL. Production and circulation matbers are handled by ALA Central Production Unit, at the above adoress

News editor John V Crowiey, Assistant Director of ubraries. Miline Library, State University College. Oneconta NY 13820 telephone $(607) 431-2725$. Assistant news editon Ellen L Muyler. Assistant Lorarian, Acquisibons Department. Milne U. brary. State University College Oneonts. NY 13820 . Editor Richard D. Johnson Mine Lbrary, State University Collegt. Oneonta. NY 13820 President ACRL Evan I Farbe Euccu. tive Secretary. ACRL Julie A Carroll Virgo

College $\&$ fiesearch Libraries is published by the Association of Collewe and Research Ubraries. a division of the Amencan if Drary Asscciation, 17 smes vearly -6 bimonthly journgl issues and 11 monthly (combining July Aurust) Nems issues - at 60 E. Hufon St, Chicago. IL 60611 . Subscriotion $\$ 2500$ a year. or to members of the division, $\$ 12.50$, included in dues. Second-class postage paid at Chicago, Illinois, and at additional mailing offices.

American Librafy Association 1978 . All material in tha joumal sabject to copyright by the American Library Association may be photocoped for the noncommercial purpose of scientific of educational advancement. 